\title{
Effects of Pre-Cooking with Acetic Acid and Citric Acid on Residual Arsenic Content in Rice
}

\author{
Roya Behrouzi ${ }^{1}$, Mohammad Hossein Marhamatizadeh ${ }^{2 *}$, Shahram Shoeibi ${ }^{3}$, \\ Vadood Razavilar ${ }^{1}$, Hossein Rastegar ${ }^{1}$ \\ ${ }^{1}$ Department of Food Industries, Islamic Azad University, Tehran, Iran \\ ${ }^{2}$ Department of Food Hygiene, Faculty of Veterinary Medicine, Kazerun Branch, \\ Islamic Azad University, Kazerun, Iran \\ ${ }^{3}$ Food and Drug Control Laboratories, Food and Drug Deputy, Ministry of Health and Medical Education, Tehran, Iran
}

Received: 11 February 2018

Accepted: 17 April 2018

\begin{abstract}
The present research was done to study the effects of the pre-cooking process of rice with acetic acid and citric acid on the concentration of residual arsenic. Rice samples were treated with soaking ( $2 \mathrm{~h}$ ) and boiling (20 min) in acetic acid (1\%)and citric acid (1\%). Analyses of arsenic was done using atomic absorption equipped with a GTA-120 graphite furnace atomizer and deuterium lamp. Limit of detection (LOD) and limit of quantification (LOQ) of arsenic were $6 \mathrm{ng} / \mathrm{g}$ and $25 \mathrm{ng} / \mathrm{g}$, respectively. The mean concentration of residual arsenic in primary rice samples was $356 \pm 14.7 \mathrm{ppb}$. The mean concentration of arsenic in rice samples processed with soaking in acetic and citric acids and boiling in acetic and citric acids were $186.1 \pm 6.9,68.2 \pm 3.6,99.7 \pm 10.3$ and $129.0 \pm 8.3 \mathrm{ppb}$, respectively. The highest reeducation percentage was obtained in boiling with citric acid $(80 \%)$. Boiling of rice samples with citric acid for 20 min can be a convenient way to reduce the concentration of residual arsenic in both the manufacturing and home-cooking processes.
\end{abstract}

Keywords: rice, residual arsenic, acetic acid, citric acid, pre-cooking

\section{Introduction}

Plants are the main way of toxic elements and especially arsenic (As) transfer from contaminated soil to humans. In As-contaminated soil, plants can uptake more heavy metal and accumulate it in different organs and especially edible parts $[1,2]$. This phenomenon is especially important for crops with high consumption rates, like rice [1-3].

*e-mail: Drmarhamati@gmail.com
Rice is the most important grain crop worldwide. It is the main source of nutrition for about $60 \%$ of the world's population [2-6]. It is grown widely in Asia, southern Europe, the southern USA, and Africa [26]. The protein component in rice is quite low $(7-10 \%$ by weight), but it forms a major source of protein $(50 \%)$ in developing countries [3-6]. Rice is also the second-highest consumption food among Iranian people. It is the most common crop grown in agricultural lands in Iran [3-6]. Therefore, it is important to inhibit the chemical and especially As contamination of rice [2-6]. 
Arsenic is a naturally occurring element present in water, soils and rock. It is also a toxic element and both organic and inorganic As compounds have been used widely in agriculture and livestock management as insecticides, pesticides, and antibiotics. It is also increased in the soil due to several activities such as base and precious metal mining and processing, ground and wastewater irrigation, sewage sludge in the field and fertilizer application [3-6].

The most important types of As in rice are inorganic As (a class 1 non-threshold carcinogen) and dimethyl arsinic acid (DMA). Additionally, traces of mono methyl arsonic acid (MMA) have also been reported in rice [3-7]. Arsenic is highly toxic in its in organic form. Long-term exposure to As from drinking water and food can cause cancer and skin lesions. It has also been associated with cardiovascular diseases and diabetes. Early childhood exposure has been linked to negative impacts on cognitive development and increased mortality in young adults [3-7].

The allowed limit concentration of As in rice has been announced from 100 parts per billion (ppb) by the Food and Drug Organization (FDA) [8]. Therefore, it is important to decrease the content of As in rice less than the allowed limit concentration announced by different organizations. Different methods have been developed for decreasingthe residual As in rice $[9,10]$. However, none of them areeconomical. Additionally, all of them are industrial methods. Therefore, it is important to develop novel methods to decrease or eliminate residual As in rice.

According to the high consumption rate of rice among Iranian people, high content of residual As in rice and the lack of applied methods for decreasing the content of As in rice, the present research was done in order to study the effects of acetic acid and citric acid on the concentration of As element in Iranian rice.

\section{Materials and Methods}

\section{Ethical Consideration}

The current research was approved by the Ethical Council of Research of the Faculty of Veterinary Medicine, Islamic Azad University, Science and Research Branch, Tehran, Iran. Verification of this research project and the licenses related to sampling process were approved by Prof. Vadood Razavilar and Dr. Mohammd Hosein Marhamatizadeh.

\section{Chemicals and Solutions}

Analytical reagent-grade chemicals were purchased from Merck Company (Merck, Darmstadt, Germany). Water purified in a Milli-Q system (Elga Lab water, Wycombe, Bucks, UK) was applied for all solutions and dilutions. Standard stock solution of As with a concentration of $1000 \mathrm{ug} / \mathrm{ml}$ was purchased from the
Sigma Aldrich company (Sigma Aldrich, St. Louis, MO, USA). The working standard solutions of As were achieved from the intermediate standard solution by adding $10 \%(\mathrm{~m} / \mathrm{v})$ hydroxylamine hydrochloride, $1 \%(\mathrm{~m} / \mathrm{v}) \mathrm{KI}$ and $0.8 \%(\mathrm{~m} / \mathrm{v})$ ascorbic acid and further diluted to $25 \mathrm{ml}$ by $10 \% \mathrm{HCl}$.

\section{Instrumental Condition}

Digestion and mineralization of rice samples were done using the Speed Wave 4 microwave digestion system (Berghof Products + Instruments GmbH, Eningen, Germany) in Teflon reaction vessels, with a maximum pressure of 40 bar and a maximum temperature of $230^{\circ} \mathrm{C}$. The As detection was done using a Varian Spectra AA 240FS atomic absorption spectrometer (Varian Australia, Pty Ltd, Mulgrave, Victoria, Australia) equipped with a GTA-120 graphite furnace atomizer and deuterium lamp as a background corrector. Arsenic was identified by a VGA-77 hydride vapor generation system (Varian Australia, Pty Ltd, Mulgrave, Victoria, Australia) with air/acetylene flame. The operating parameters were as follows:wavelength $193.7 \mathrm{~nm}$, slit width $0.5 \mathrm{R} \mathrm{nm}$, gain $66 \%$, lamp current of $6.0 \mathrm{~mA}$ and lamp position 4. Airflow and acetylene flow were adjusted to 13.5 and $2.1 \mathrm{~L} / \mathrm{min}$, respectively.

\section{Sample Preparation}

From June 2017 to August 2017, rice samples were collected from the lands in northern Iran, which are famous for rice. Additionally, rice from northern Iran has been transported to many sites of the world. Therefore, it is important to check the chemical quality of these rice samples. Rice samples were purchased from rice farms in northern Iran (Sari, Iran). The effects of the precooking process on reducing arsenic contamination were estimated on naturally contaminated whole rice samples. In this context, 22 ground rice samples were evaluated for the effect of citric acid and acetic acid on the concentration of As. Preparation of rice samples was done according to traditional cooking in a laboratory prior to As extraction. Rice samples were primarily washed six times using deionized water. Then, rice cooking was done in two forms: Kateh and infusion. In the Kateh cooking method, the rice samples were soaked separately in citric acid $1 \%$ and acetic acid $1 \%$ for $2 \mathrm{~h}$. After soaking, rice samples were washed three times using deionized water. In the infusion cooking method, rice samples were boiled separately in citric acid $1 \%$ and acetic acid $1 \%$ for $20 \mathrm{~min}$. After boiling, rice samples were washed three times using deionized water.

\section{Arsenic Extraction and Analysis}

Arsenic extraction was done using the method described by the Iranian National Standard Organization (No. 16722). Briefly, $2 \mathrm{~g}$ of rice samples were weighed 
Table 1. Results of analysis of arsenic metal in rice samples with different preparation operations $(n=22)$.

\begin{tabular}{|c|c|c|c|c|c|c|}
\hline \multirow{2}{*}{ Real Sample } & \multicolumn{6}{|c|}{ Arsenic concentration (ppb) } \\
\hline & $\begin{array}{c}\text { Primary rice } \\
\text { samples }\end{array}$ & $\begin{array}{l}\text { Soaking in water } \\
\text { (6 times) }\end{array}$ & $\begin{array}{l}\text { Soaking in acetic } \\
\text { acid }(2 \mathrm{~h})\end{array}$ & $\begin{array}{l}\text { Soaking in citric } \\
\text { acid }(2 \mathrm{~h})\end{array}$ & $\begin{array}{l}\text { Boiling in acetic } \\
\text { acid (20 min) }\end{array}$ & $\begin{array}{l}\text { Boiling in citric } \\
\text { acid }(20 \mathrm{~min})\end{array}$ \\
\hline S1 & 340 & 200 & 90 & 130 & 180 & 65 \\
\hline S2 & 342 & 201 & 90 & 130 & 180 & 65 \\
\hline S3 & 340 & 200 & 90 & 135 & 185 & 70 \\
\hline S4 & 370 & 210 & 95 & 140 & 180 & 70 \\
\hline S5 & 345 & 205 & 90 & 135 & 180 & 65 \\
\hline S6 & 384 & 250 & 120 & 120 & 180 & 75 \\
\hline S7 & 345 & 200 & 95 & 140 & 190 & 65 \\
\hline S8 & 348 & 202 & 100 & 120 & 190 & 65 \\
\hline S9 & 370 & 210 & 95 & 125 & 190 & 68 \\
\hline S10 & 348 & 202 & 95 & 125 & 180 & 65 \\
\hline S11 & 350 & 205 & 95 & 125 & 190 & 65 \\
\hline S12 & 354 & 208 & 95 & 120 & 200 & 68 \\
\hline S13 & 348 & 202 & 96 & 130 & 180 & 68 \\
\hline S14 & 354 & 207 & 115 & 120 & 185 & 68 \\
\hline S15 & 380 & 245 & 95 & 125 & 185 & 75 \\
\hline S16 & 349 & 202 & 94 & 120 & 180 & 68 \\
\hline S17 & 350 & 208 & 95 & 140 & 180 & 68 \\
\hline S18 & 352 & 208 & 120 & 130 & 190 & 68 \\
\hline S19 & 384 & 253 & 98 & 140 & 190 & 75 \\
\hline S20 & 350 & 210 & 95 & 120 & 180 & 65 \\
\hline S21 & 345 & 210 & 115 & 120 & 200 & 65 \\
\hline $\mathrm{S} 22$ & 384 & 220 & 120 & 147 & 200 & 75 \\
\hline Mean $\pm \mathrm{SD}^{*}$ & $356.00 \pm 14.70$ & $211.70 \pm 15.70$ & $99.70 \pm 10.30$ & $129.00 \pm 8.30$ & $186.10 \pm 6.90$ & $68.20 \pm 3.60$ \\
\hline
\end{tabular}

${ }^{*}$ Mean \pm Standard deviation

per beaker. Then, $2.5 \mathrm{ml}$ of ashing aid solution $\left(\mathrm{MgO} 2 \%+\mathrm{MgNo}_{3} 20 \%\right)$ and $5 \mathrm{ml}$ of nitric acid $6.5 \%$ were added. Samples were completely dried on a heater at $70^{\circ} \mathrm{C}$. Samples were placed in a furnace at $450^{\circ} \mathrm{C}$ for $6 \mathrm{~h}$. Then, $5 \mathrm{ml}$ nitric acid $6.5 \%$ were added to solutions of the previous stage and placed on the heater until dried completely. Then, solutions wereplaced ina furnace at $450^{\circ} \mathrm{C}$ for $90 \mathrm{~min}$. In the final step, $1 \mathrm{ml}$ deionized water was added to the solution. Then $5 \mathrm{ml} \mathrm{HCl} 50 \%$ and $5 \mathrm{ml}$ KI $2.5 \%$ with $2 \%$ ascorbic acid were added to solution of the previous stage in order to reachthe total volume of $10 \mathrm{ml}$. After $30 \mathrm{~min}$, the achieved solution was injected into the atomic absorption device [11].

\section{Quality Assurance}

For estimating the reliability of the results obtained from As analysis, the accuracy and precision of the method were assessed. Recovery of the As was recorded by analyzing a blank rice sample spiked with 25, 50, 100 and $200 \mathrm{ng} / \mathrm{g}$ of As $(\mathrm{n}=3)$. The calibration curve for As was linear in the range of $25-200 \mathrm{ng} / \mathrm{g}$ $\left(\mathrm{R}^{2}=0.9979\right)$. The mean recovery for arsenic was $99.258 \%$ (RSDr $=9.9-19.6 \%$ ). Limit of detection (LOD) and limit of quantification (LOQ) for As were $6 \mathrm{ng} / \mathrm{g}$ and $25 \mathrm{ng} / \mathrm{g}$, respectively. Both the recoveries and repeatability are in accordance with the criteria set by the Codex standard 193-1995 [12].

\section{Results and Discussion}

Table 1 represents the results of analysis of the concentration of arsenic (As) element in rice samples with different preparation operations $(n=22)$. The highest and lowest concentrations of arsenic in studied 
Table 2. Comparison of the reduction percentage of arsenic in rice samples processed with different pre-cooking methods.

\begin{tabular}{|c|c|c|c|c|c|}
\hline \multirow{2}{*}{$\begin{array}{c}\text { Mean reduction percent in } \\
\text { arsenic/Treatments }\end{array}$} & $\begin{array}{c}\text { Boiling in citric } \\
\text { acid }(20 \mathrm{~min})\end{array}$ & $\begin{array}{c}\text { Boiling in acetic } \\
\text { acid }(20 \mathrm{~min})\end{array}$ & $\begin{array}{c}\text { Soaking in citric } \\
\text { acid }(2 \mathrm{~h})\end{array}$ & $\begin{array}{c}\text { Soaking in acetic } \\
\text { acid }(2 \mathrm{~h})\end{array}$ & $\begin{array}{c}\text { Soaking in water } \\
(6 \text { times })\end{array}$ \\
\cline { 2 - 6 } & 80 & 47.70 & 63.20 & 71.90 & 40.44 \\
\hline
\end{tabular}

samples were 380 and $340 \mathrm{ppb}$, respectively. The mean concentration of As in primary rice samples was $356.0 \pm 14.7 \mathrm{ppb}$. We found that the mean concentration of As in rice samples processed with soaking in acetic acid, soaking in citric acid, boiling in acetic acid and finally boiling in citric acid were $99.7 \pm 10.30,129.0 \pm 8.30$, $186.10 \pm 6.90$ and $68.20 \pm 3.60 \mathrm{ppb}$, respectively. The mean concentration of As in rice samples washed with deionized water (6 times) was $211.70 \pm 15.70 \mathrm{ppb}$.

Table 2 represents the percentage reduction of As in rice samples processed with different pre-cooking methods. We found that reduction percentage of the As in rice samples soaking in acetic acid, soaking in citric acid, boiling in acetic acid and finally boiling in citric acid methods were $71.90 \%, 63.20 \%, 47.70 \%$ and $80 \%$, respectively. Six times washing of rice samples using the deionized water caused a $40.44 \%$ reduction in As content.

Consumption of rice contaminated with heavy metals and especially As for a long period of time causes severe clinical diseases and syndromes, including cancer, chromosomal mutations, and malformation. Therefore, finding a convenient and easy way to reduce the content of residual As in highly consumed foods and especially rice can prevent the occurrence of such dangerous disorders.

As far as we know, the present study is the first report of the reducing effects of citric acid and acetic acid on the content of residual As in Iranian rice. We found that using both citric acid and acetic acid caused considerable reducing effects on the content of As in rice. However, reducing the effect of citric acid was far more than acetic acid. We also found that boilingrice samples with citric acid had the highest reducing effects on the content of As in rice samples. As it showed, the mean concentration of residual As in studied rice samples $(356.0 \pm 14.7 \mathrm{ppb})$ were higher than the allowed limit concentration as determined by the National Standard Organization of Iran $(0.15 \mathrm{mg} / \mathrm{kg})$ (Institute of Standards and Industrial Research of Iran (ISIRI) 12968) [13]. Detected concentrations were also higher than the allowed limit concentration announced by the FDA (100 ppb) [8]. It was also higher than the allowed limit concentration determined by the Codex (150 ppb) [12]. Therefore, using the rice samples even for a short period of time is a serious risk factor for the occurrence of the aforementioned diseases and disorders.

Food processing such as washing, soaking, peeling and cooking causeda significant reduction in the content of food contaminants such as heavy metals, pesticides and mycotoxins. Soaking and boiling are two of the most commonly used processing methods both at the industrial and domestic levels. Results of the present investigation showed that boiling and soaking of rice samples with citric acid and acetic acid caused a considerable decrease in the content of residual As. We found that the mean concentration of As in rice samples processed with soaking in acetic acid and boiling in citric acid were $99.7 \pm 10.30$ and $68.20 \pm 3.60$ ppb, respectively, which both were lower than the primary concentration of As and also the allowed limit concentration announced by the ISIRI, FDA and Codex $[8,12,13]$.

Several studies have been conducted in this field. A previous report [14] looked at the effect of rinse washing, low volume (2.5:1 water:rice) and high volume (6:1 water:rice) cooking, and steaming on the content of residual As in rice. Results showed that rinse washing was effective at removing about $10 \%$ of the total and inorganic As from basmati rice, but was less effective for other rice types. The steaming method reduced total and inorganic As rice content, while it did not do so consistently across all rice types investigated. Low-volume water cooking did not remove As. Highvolume water cooking did effectively remove both total and inorganic As for the long-grain and basmati rice (parboiled was not investigated in high-volume cooking water experiment), by $35 \%$ and $45 \%$ for total and inorganic As content, respectively, compared to raw rice [14]. Signes et al. (2008) [14] reported that the method of rice cooking and also type of rice samples were effective on the content of residual As. They showed that cooking water and raw and boiled Atabrice contained $40 \mu \mathrm{g} / 1$ As and 185 and $315 \mu \mathrm{g} / \mathrm{Kg}$ As, respectively. In general, all cooking methods increased total As from the levels in raw rice; however, raw boiled rice decreased its total As by $12.7 \%$ when cooked by the traditional method, but increased by $15.9 \%$ or $23.5 \%$ when cooked by the intermediate or contemporary methods, respectively. Based on the best possible scenario (the traditional cooking method leading to the lowest level of contamination, and the Atab rice type with the lowest As content), total As daily intake was estimated to be $328 \mathrm{mg}$, which was twice the tolerable daily intake of $150 \mathrm{mg}$. A recent investigation [15] compared the effects of two dehusking processes of wet (soaking of rice, boiling and mechanical hulling) and dry (mechanical hulling) on the content of residual As in rice. Findings obtained from this report showed that hulling of paddy rice $(373 \mu \mathrm{g} / \mathrm{kg}$ As) significantly decreased As content in rice grain $(311 \mu \mathrm{g} / \mathrm{kg} \mathrm{As})$. The final As concentrations in boiled rice (final product of the wet process) and atab rice (dry process) were 332 and $290 \mu \mathrm{g} / \mathrm{kg}$ As. Thus, the dry method is recommended for dehusking 
paddy rice if As-free water is not available. However, villagers can reduce the As content in the wet system by discarding the soaking water and using new water for light boiling. Yim et al. (2017) [16] studied the effect of polishing, stirring and rinsing, soaking, or pressure-steam cooking on total organic and inorganic As content in rice samples. They revealed that with increasing numbers of rinses and times stirred per rinse, the total As content significantly decreased by $27.6 \%$ in brown rice and $39.0 \%$ in white rice with a $10 \%$ degree of polishing (10 DOP\%). The increase in ratio of water to rice from $1.5: 1$ to $6: 1$ reduced total As by 4.4 to $7.5 \%$, depending on soaking time. The total As concentrations found in samples prepared using the optimal process for cooked brown rice and for white rice with $5 \mathrm{DOP} \%$, $7 \mathrm{DOP} \%$, and $10 \mathrm{DOP} \%$ were 56.1, 49.6, 52.0, and $42.0 \%$, respectively, compared with those after bran residues were removed. As far as we know, the reported concentration of As in rice samples was the highest report of the residual As in rice samples in the world. Similar results were reported by Naito et al. (2015) [17], who reported that total and inorganic As levels in three white rice samples polished by removing $10 \%$ of bran by weight were reduced to $61-66 \%$ and $51-70 \%$ of those in brown rice. They showed that the As levels in the white rice after three washings with deionized water were reduced to $81-84 \%$ and $71-83 \%$ of those in raw rice. Other studies reported that temperature degree and time of cooking of foodstuffs and especially rice caused a decrease in the content of chemical contaminants and especially As [9, 18].

The current study was focused on the using of the infusion and kateh rice cooking popular methods. These methods are affiliated with using boiled water for a considerable period of time. The highest reduction percentage of As was shown in boiling preparation method in citric acid 1\% (80\%). However, the lowest decrease in the content of As was reported for rice rinsing with deionized water (40.44\%). Therefore, boiling of rice samples in citric acid in both modes of infusion and kateh leads to an $80 \%$ reduction in the content of As. Signes-Pastor et al. (2017) [19] reported the considerable effects of pre-cooking procedures, including rinsing and peeling on the reduction of heavy metals and especially As in foodstuffs. Al-Saleh and Abduljabbar (2017) [20] reported that the mean level of As in rice grain samples was $0.202(0.183) \mu \mathrm{g} / \mathrm{g}$ dry weight. They showed that the mean concentration of As in rice samples soaked in water and those rinsed three times with water were 0.202 and $0.183 \mu \mathrm{g} / \mathrm{g}$ dry weight, which showed the higher effects of the soaking procedure in water. Soaking or rinsing rice grains with water decreased As levels in all brands but not to safe levels $[19,20]$. Therefore, soaking or rinsing rice grains only with water is not sufficient to reduce the risk of residual As.

Documented data have revealed that using a suitable method to reduce the content of residual lead is dependent on the type of foodstuff, type of chemical contaminants and time of processing stage [21]. Temperature, time and method of cooking were introduced as gold factors for reducing the content of As in rice [22]. Chen et al. (2003) [23] reported the considerable effects of organic acids like citric acid and acetic acid on reducing As and other types of heavy metals in different types of foodstuffs. However, their reported method was not applied and the percentage of reduction was lower than our findings. High effects of organic acids like acetic acid and citric acid were reported for reducing heavy metals in different types of foodstuffs [24].

The main reason for the high effects of the citric acid and acetic acid on the content of residual As in rice is the fact that the combination of acidic $\mathrm{pH}$ and high temperature might lead to changes in the chemical forms of metals or dissociate them from the food proteins [25]. $\mathrm{pH}$ has always been one of the factors investigated in studies performed on heavy metal reduction in foods. These organic ring compounds include many organic acids such as lactic acid, acetic acid, citric acid, and ascorbic acid, which are classified as weak acids and have the ability to sequester or seize metal atoms such as As, mercury, cadmium, and lead [25]. Therefore, using organic acids and especially citric acid and acidic acid as chelating agents is effective for reducing the content of residual As in rice. The high presence of As and other types of toxic heavy metals have also been reported from Iran [26-29]. Xu et al. (2014) [30] reported that the content of residual heavy metals in rice in the deep solutions were safe according to the environmental quality standard for groundwater. They showed that irrigation management has a significant effect on the content of residual toxic heavy metals in rice. Tahir Amin et al. (2017) [31] reported that using date palm fibers and orange peel in agricultural lands caused a significant decrease in the content of toxic heavy metals, which showed the effect of management in the content of heavy metals in plans. Razafsha et al. (2016) [32] reported that using sour lemon peel caused a significant decrease in the content of heavy metal in rice. They showed that cooking rice by soaking rinsed rice samples by $\mathrm{NaCl} 2 \%$ and sour lemon peel modified by phosphoric acid $1 \%$ at least for 1 hours had the greatest effect $(P<0.001)$ with regards to lowering lead and cadmium levels in cooked rice. Specifically, it preferentially reduced the cadmium content by $96.40 \%$, nickel content by $67.90 \%$ and lead content by $90.11 \%$ from the raw rice, when combined with rinse washing and being soaked by salt for one-hour contact time. Similar findings have been reported by Naseri et al. (2014) [33].

\section{Conclusion}

In conclusion, we identified an easy and safe method based on the soaking and boiling of rice samples in citric acid and acetic acid for removing or reducing 
the content of residual As in rice samples. We found that the mean concentration of As in Iranian rice samples was $356 \pm 14.7 \mathrm{ppb}$, which was higher than the allowed limit concentration announced by different health-related organizations. The mean concentration of As in rice samples processed with soaking in acetic acid, soaking in citric acid, boiling in acetic acid and finally boiling in citric acid were $99.7 \pm 10.30$, $129.0 \pm 8.30, \quad 186.10 \pm 6.90$ and $68.20 \pm 3.60 \mathrm{ppb}$, respectively. We found an $80 \%$ decrease in the content of As prior to treatment with citric acid. Additionally, reducing the effects of acetic acid were also considerable. Citric acid is the main organic acid in lemon juice and acetic acid is the main one in vinegar. Therefore, household soaking and boiling of rice in vinegar and especially lemon juice are efficient, safe, simple and rapid methods for decreasing the content of residual lead in rice.

\section{Acknowledgements}

The authors would like to thank Mr. Hamid Karimaneh for his important support of our research project. We also thank the staff of the Food and Drug Administration of Iran for laboratory support. The current research was financially supported by Islamic Azad University, Science and Research Branch, Tehran, Iran.

\section{Conflict of Interest}

The authors declare no conflict of interest.

\section{References}

1. DARGAHI A., GOLESTANIFAR H., DARVISHI P., KARAMI A., HASAN SH., POORMOHAMMADI A., BEHZADNIA A. An investigation and comparison of removing heavy metals (lead and chromium) from aqueous solutions using magnesium oxide nanoparticles. Pol. J. Environ. Stud. 25 (2), 557, 2016.

2. ALAVI S., SHAMSHIRI S., PARIZ Z., DARGAHI A., MOHAMMADI M., FATHI S., AMIRIAN T. Evaluating the palm leaves efficiency as a natural adsorbent for removing cadmium from aqueous solutions: Isotherm adsorption study. IJPT, 8 (2), 13919, 2016.

3. ĆURKOVIĆ M., SIPOS L., PUNTARIĆ D., DODIGĆURKOVIĆ K., PIVAC N., KRALIK K. arsenic, copper, molybdenum, and selenium exposure through drinking water in rural Eastern Croatia. Pol. J. Environ. Stud. 25 (3), 981, 2016.

4. FARROKHI M., NAIMI-JOUBANI M., DARGAHI A., POURSADEGHIAN M., JAMALI HA. Investigating activated sludge microbial population efficiency in heavy metals removal from compost leachate. Pol. J. Environ. Stud, 27 (2), 623, 2018.

5. ALMASI A., DARGAHI A., AHAGH M., JANJANI H., MOHAMMADI M., TABANDEH L. Efficiency of a constructed wetland in controlling organic pollutants, nitrogen, and heavy metals from sewage. JCHPS, 9 (4), 2924, 2016.

6. NEMATI S., MOSAFERI M., OSTADRAHIMI A., MOHAMMADI A. Arsenic intake through consumed rice in Iran: markets role or government responsibility. Health. Promot, 4 (2), 180, 2014.

7. ASIF IMRAN M., AHMAD SAJID Z., NAWAZ CHAUDHRY M. Arsenic (As) Toxicity to Germination and Vegetative Growth of Sunflower (Helianthus annuus L.). Pol. J. Environ. Stud. 24 (5), 1993, 2015.

8. Food and Drug Administration (FDA). Department of Health and Human Services, Center for Food Safety and Applied Nutrition. Arsenic in Rice and Rice Products Risk Assessment Report. U.S. 2016.

9. CAREY M., JIUJIN X., FARIAS J.G., MEHARG A.A. Rethinking rice preparation for highly efficient removal of inorganic arsenic using percolating cooking water. Plos. One, 10 (7), e $0131608,2015$.

10. DIXIT G., SINGH A.P., KUMAR A., DWIVEDI S., DEEBA F., KUMAR S., SUMAN S., ADHIKARI B., SHUKLA Y., TRIVEDI P.K. Sulfur alleviates arsenic toxicity by reducing its accumulation and modulating proteome, amino acids and thiol metabolism in rice leaves. Sci. Rep, 5, 16205, 2015.

11. BSEN. Foodstuffs - Determination of trace elements Determination of total arsenic by hydride generation atomic absorption spectrometry (HGAAS) after dry ashing, 2005.

12. CODEX. Codex General Standard for contaminants and toxins in food and feed, 2010.

13. ISIRI. Food and Feed-Maximum limit of heavy metals National standard; Institute of Standards and Industrial Research of Iran, 2010.

14. SIGNES A., MITRA K., BURLÓ F., CARBONELLBARRACHINA A.A. Effect of cooking method and rice type on arsenic concentration in cooked rice and the estimation of arsenic dietary intake in a rural village in West Bengal, India. Food. Addit. Contam, 25 (11), 1345, 2008.

15. SIGNES A., MITRA K., BURLÓ F., CARBONELLBARRACHINA A. Effect of two different rice dehusking procedures on total arsenic concentration in rice. Eur. Food. Res. Technol, 226 (3), 561, 2008.

16. YIM S.-R., KIM J.H., CHOI M.-H., PARK G.Y., SHIM S.-M., CHUNG M.-S. Systematic Investigation of the Reduction of Inorganic Arsenic and Bioactive Nutrients in Rice with Various Cooking Techniques. J. Food. Protect, 80 (11), 1924, 2017.

17. NAITO S., MATSUMOTO E., SHINDOH K., NISHIMURA T. Effects of polishing, cooking, and storing on total arsenic and arsenic species concentrations in rice cultivated in Japan. Food. Chem, 168, 294, 2015.

18. RAAB A., BASKARAN C., FELDMANN J., MEHARG A.A. Cooking rice in a high water to rice ratio reduces inorganic arsenic content. J. Environ. Monitor, 11 (1), 41, 2009.

19. SIGNES-PASTOR A.J., CAREY M., MEHARG A.A. Inorganic arsenic removal in rice bran by percolating cooking water. Food. Chem, 234, 76, 2017.

20. AL-SALEH I., ABDULJABBAR M. Heavy metals (lead, cadmium, methylmercury, arsenic) in commonly imported rice grains (Oryza sativa) sold in Saudi Arabia and their potential health risk. Int. J. Hyg. Envir. Heal, 220 (7), 1168, 2017. 
21. KAUSHIK G., SATYA S., NAIK S. Food processing a tool to pesticide residue dissipation - A review. Food. Res. Int, 42 (1), 26, 2009.

22. PERELLÓ G., MARTÍ-CID R., LLOBET J.M., DOMINGO J.L. Effects of various cooking processes on the concentrations of arsenic, cadmium, mercury, and lead in foods. J. Agr. Food. Chem, 56 (23), 11262, 2008.

23. CHEN Y., LIN Q., LUO Y., HE Y., ZHEN S., YU Y., TIAN G., WONG M. The role of citric acid on the phytoremediation of heavy metal contaminated soil. Chemosphere, 50 (6), 807, 2003.

24. SONG S., WANG L., WANG X., QI G., YU L., LIU J. Speciation Analysis and Removal of Heavy Metals Zn, $\mathrm{Cu}, \mathrm{Cd}$ from Sludge by Organic Acid. $5^{\text {th }}$ International Conference on Advanced Design and Manufacturing Engineering (ICADME), 815, 2015.

25. HAJEB P., SLOTH J.J., SHAKIBAZADEH S., MAHYUDIN N., AFSAH-HEJRI L. Toxic elements in food: Occurrence, binding, and reduction approaches. Compr. Rev. Food. Sci. F, 13 (4), 457, 2014.

26. ZOHREHVAND F., TAKDASTAN A., MOHAMMADI M.J., JAAFARZADEH N., RAMEZANI Z., YARI A.R. Study of heavy metals in vegetable irrigated with surface water from farmlands in Ahvaz city, Iran. Fresenius. Environ. Bull, 26 (11), 6932, 2017.

27. ESMAILI A., KARBASDEHI V.N., SAEEDI R., MOHAMMADI M.J., SOBHANI T., DOBARADARAN $\mathrm{S}$. Data on heavy metal levels $(\mathrm{Cd}, \mathrm{Co}$, and $\mathrm{Cu})$ in wheat grains cultured in Dashtestan County, Iran. Data. Brief, 14, 543, 2017.

28. DOBARADARAN S., SOLEIMANI F., NABIPOUR I., SAEEDI R., MOHAMMADI M.J. Heavy metal levels of ballast waters in commercial ships entering Bushehr port along the Persian Gulf. Marine. Poll. Bull, 126, 74, 2018.

29. NEISI A., GOUDARZI G., AKBAR BABAEI A., VOSOUGHI M., HASHEMZADEH H., NAIMABADI A., MOHAMMADI M.J., HASHEMZADEH B. Study of heavy metal levels in indoor dust and their health risk assessment in children of Ahvaz city, Iran. Toxin. Rev, 35 (1-2), 16, 2016

30. XU J., WEI Q., YU Y., PENG S., YANG S. Leaching of Heavy Metals from Rice Fields with Different Irrigation Management. Pol. J. Environ. Stud. 23 (6), 2279, 2014.

31. TAHIR AMIN M., ALAZBA A.A., NASIR AMIN M. Absorption behaviours of copper, lead, and arsenic in aqueous solution using date palm fibers and orange peel: kinetics and thermodynamics. Pol. J. Environ. Stud. 26 (2), 543, 2017.

32. RAZAFSHA A., ZIARATI P., MOSLEHISHAD M. Removal of Heavy Metals from Oryza sativa Rice by Sour Lemon Peel as Bio-sorbent. Biomed Pharmacol J, 9 (2), 543, 2016.

33. NASERI M., RAHMANIKHAH Z., BEIYGLOO V., RANJBAR S. Effects of two cooking methods on the concentrations of some heavy metals (cadmium, lead, chromium, nickel and cobalt) in some rice brands available in Iranian market. J. Chem. Health. Risk, 4 (2), 65, 2014. 